\title{
Population mobility and sustainable development in the Mamminasata Metropolitan South Sulawesi, Indonesia
}

\author{
Batara Surya" ${ }^{* 1}$ Emil Salim Rasyidi ${ }^{1}$, Herminawaty Abubakar ${ }^{2}$, Muhammad \\ Idris $^{2}$ \\ ${ }^{1}$ Faculty of Engineering, Bosowa University, Indonesia \\ ${ }^{2}$ Faculty of Economics and Business, Bosowa University, Indonesia
}

Economic growth and urban agglomeration have triggered an increase in the size and mobility of the Metropolitan Mamminasata urban population. This study aims to analyse spatial interactions working as a determinant of connectivity of the transportation system and the growth of suburban areas toward smart and sustainable cities in the Mamminasata Metropolitan urban system and the effects that spatial expansion, spatial integration, urban agglomeration, spatial use, and the transportation system have on population mobility. The research method used is a sequential explanatory design that combines quantitative and qualitative research methods. The results show that the coefficients of determination are as follows: spatial expansion to population mobility $-4.90 \%$, spatial integration to population mobility $-2.99 \%$, spatial interaction to population mobility $-4.87 \%$, urban agglomeration to population mobility $-2.09 \%$, space use to population mobility $-2.64 \%$, and transportation system to population mobility $-5.15 \%$. The results of this study will assist in the formulation of development policies, management of the urban transportation system, and allocation of space utilisation going forward.

Key Words: population mobility; spatial integration; spatial interaction; coreperiphery

Article Info: Received: February 10, 2021; Revised: April 24, 2021; Accepted: November 3, 2021; Online: November 30, 2021.

\footnotetext{
"Corresponding author

Address: Department of Urban and Regional Planning, Faculty of Engineering, Bosowa University, Makassar City, 90231 South Sulawesi, Indonesia

Phone: (0411) 452901| Email: bataraciptaperdana@yahoo.co.id
}

(C)2021 Human Geographies; The authors

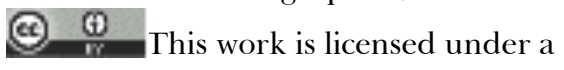

Creative Commons Attribution 4.0 International License. DOI:10.5719/hgeo.2021.152.6 


\section{Introduction}

The growth and development of metropolitan urban areas in Indonesia are revealed to have a fundamental difference compared with the spatial function that forms in metropolitan cities in developed countries. Urban regions worldwide are increasingly facing the challenge of dealing with highly dynamic metropolitan growth and, at the same time, institutional changes such as decentralization and globalization (Woltjer, 2014). Economic globalization, in general, is marked by the modernization and industrialization of big cities and metropolitan areas that are supported by the advancement of information technology, communication, and transportation. In this context, increasing the economic productivity of metropolitan cities is a driving force for the mobility of people, goods, capital, services, and ideology. Global economic activity is not only formed in urban centres but also extends and ultimately impacts the surrounding area. Therefore, restructuring the global economy has a profound effect on the composition of the socioeconomic population of big cities (Sassen, 1991; Utami, 2020).

World Bank reports that 220 million Indonesians will live in cities and towns by 2045 . Urbanisation in Indonesia is predicted to increase to $70 \%$. However, every $1 \%$ increase in urbanisation is only able to leverage $1.4 \%$ of per capita GDP. This figure is much smaller compared with China, where every $1 \%$ increase in urbanisation is able to yield a GDP per capita increase of up to $3 \%$ (Robberts et al., 2019). Then, every $1 \%$ increase in urbanisation in the Asia Pacific and East Asia regions can drive an average GDP per capita increase of 2.7\%. (Neiderud, 2015). Countries' economic growth has been linked to urbanisation, and countries with high per capita income are among the most urbanised. In contrast, countries with low per capita income are the least urbanised. Furthermore, population growth and urbanisation are often seen as threats to environmental quality (White et al., 2008; Surya et al., 2020).

The growth of big cities and metropolitan areas in Indonesia is divided into three categories based on their development dynamics: (i) growth in 1950 when the city of Jakarta was inhabited by more than one million inhabitants; (ii) growth in 1980, when there were three cities that had populations of over one million, namely, Surabaya, Bandung, and Medan; (iii) growth in 1990, when three cities, namely, Semarang, Palembang, and Makassar, had populations of over one million people and developed into a metropolitan city. During the last 40 years, the major cities and metropolitan areas in Indonesia have experienced excessive urbanisation and maximum compaction. The process of industrialization and urbanisation affects the distribution of income and causes income inequality (Ha et al., 2019; Surya et al., 2020).

The dynamics of Indonesian cities development changed with 2010 when the number of cities with populations above one million increased to eleven. The cities in question are Bekasi, Tangerang, Depok, and South Tangerang. These cities developed due to the mega-urbanisation process of Jakarta, which formed Jabodetabek megacities (Jakarta, Bogor, Depok, Tangerang, and Bekasi). In this context, the integration of the Jakarta City spatial system is expanding into the 
greater Jakarta area. Urban physical development then extends outwards and crosses the boundaries of the metropolitan area, spreads along major roads, and spreads randomly in all directions (Mc Gee \& Robinson, 1995). Thus, land-use patterns and landscapes have been changed and have led to a series of challenges facing urbanisation-oriented environments (Arsanjani et al., 2013; Surya, 2015).

In 2015, there was an expansion of the Makassar core city toward the Metropolitan suburb of Mamminasata. It then expanded both vertically and horizontally due to capital flows and investment development. This condition is marked by increased large-scale settlement development, industry, education, and trade and services. The sector contributed to an increase in South Sulawesi's GRDP growth of $45 \%$ in 2019. Furthermore, economic activity that continued to increase impacted population density and the distribution of land use allocations both vertically and horizontally in the Metropolitan suburbs of Mamminasata. Local positive and negative correlations exist simultaneously between the spatial distribution density and the allocation of land use scale (Giyarsih, 2001; Maheshwari et al., 2016; Yanbo et al., 2018). Urban areas are changing from densely populated cities to more diffuse patterns, or expanded into smaller cities, a condition that causes changes in spatial structure due to connectivity between cities on the periphery (Sheng et al., 2013; Grădinaru et al., 2015).

The allocation of spatial utilization of the core city of Makassar, which is dominantly developed for commercial and industrial activities, is an opportunity for the urban population of the Mamminasata Metropolitan to work and live. These conditions have an impact on population mobility, changes in typology, morphology, and conversion of productive agricultural land in the periphery. In particular, the spatial expansion of such big cities is reflected in the specific process of peri-urbanisation: the formation of mixed space midway between the city centre and rural space. Transitional space can undergo several physical, morphological, social-demographic, cultural, economic, and functional transformations (Dupont, 2005; Surya, 2015). The three elements that affect city morphology are land use, road patterns, and the characteristics of buildings (Surya, 2016). Economic growth that tends to increase becomes the driving force of population mobility and circular migration toward the core city of Makassar. One of the factors is the connectivity of the Metropolitan Mamminasata urban transportation network system. Rapid urbanisation and urban development in Indonesia and several Asian countries are characterized by increased physical growth that goes beyond metropolitan and city boundaries (McGee \& Robinson, 1995). According to the concept of interconnectivity in typology, landscape connectivity is defined as the continuity of corridors, networks, or matrices that characterize the relationship between ecological systems, such as the overall complexity (Schreiber \& Kelton, 2005), accessibility (Janssens et al., 2006), interdependency (Lan et al., 2019), and agglomeration (Wei et al., 2017).

The Metropolitan Mamminasata urban area, designated as the object of study, is the leading regional development centre in South Sulawesi Province. The intended urban areas are (i) the entire Makassar City area, which is a core city, (ii) a portion of the Gowa Regency that functions as a supporting city, (iii) a portion 
of the Maros Regency area, which functions as a supporting city, and (iv) part of the Takalar Regency as a supporting city. Furthermore, excessive urbanisation and maximum compaction in the core city led to spatial expansion and suburbanisation toward the Mamminasata Metropolitan urban suburbs. Suburbanisation can be defined by the absolute population growth in the agglomeration, with growth being relatively concentrated in the suburban space (Scheuer et al., 2016). The dynamics of rapid urbanisation are the leading causes and effects of city explosions, environmental disturbances, and the transformation of urban patterns (Al Jarah et al., 2019). Spatial integration and urban agglomeration lead to a relationship between the core city and the periphery.

Furthermore, the edge area's accelerated and rapid revolutionary development impacts population mobility and circular migration toward the core city by utilising the main Mamminasata Metropolitan urban road corridor. Transportation infrastructure (roads, public transportation systems) is a trigger for spatial dynamics that cause specific effects (rentals of floor space, offices, and apartments result in urban spread or hyper-densification), as well as gentrification (Loibl et al., 2018). The integration of cities has resulted in continued compression and fragmentation of the ecological space, and spatial interaction among city clusters should be considered in future regional planning (Tan et al., 2016; Wan et al., 2019). Urban agglomeration, changes in spatial use, and transportation system connectivity are determinants of core-periphery relations in Metropolitan Mamminasata. Thus, this study intends to answer two research questions, namely: (1) how spatial interaction works as a determinant of transport system connectivity and the growth of suburban areas toward smart and sustainable cities in the Metropolitan Mamminasata urban system, and (2) how do spatial expansion, spatial integration, urban agglomeration, space utilisation, and transportation system influence population mobility.

\section{Data and methodology}

This research uses a sequential explanatory approach, namely a combination of quantitative and qualitative research methods applied in sequence. This approach presents a complete picture of the urban Mamminasata conditions and situation to explore and clarify phenomena that develop in the field by describing several variables relating to the study area and between the phenomena tested. First, qualitative methods are used to describe the urban characteristics of Metropolitan Mamminasata to construct research hypotheses. Furthermore, quantitative methods are used to prove the hypotheses and explain the results in a descriptive, comparative, and associative way. This step was carried out carefully and holistically on the basis of field data, which showed the relationship between the phenomena under investigation.

This research was conducted in the urban core city of Makassar, Maros City Maros Regency, Sungguminasa City Gowa Regency, and Takalar City as a unified Metropolitan Mamminasata urban system (Table 1). 
Table 1. Characteristics of the Mamminasata Metropolitan Urban Area

\begin{tabular}{|c|c|c|c|c|}
\hline Urban area & $\begin{array}{c}\text { Regional } \\
\text { Geographical } \\
\text { Location }\end{array}$ & $\begin{array}{c}\text { Area } \\
\text { (hectares) }\end{array}$ & $\begin{array}{c}\text { Total } \\
\text { Population }\end{array}$ & Urban Typology \\
\hline Makassar City & $119^{\circ} 27^{\prime} 57^{\prime E} 5^{\circ} 8^{\prime} 13^{\prime \prime S}$ & 19,926 & $1,671,001$ & Coast-Lowland \\
\hline Urban Gowa Regency & $119^{\circ} 43^{\prime} 24^{\prime E} 5^{\circ} 0^{\prime} 6^{\prime \prime S}$ & 188,332 & 752,896 & Coast-Lowland \\
\hline Urban Maros Regency & $119^{\circ} 28^{\prime} 54^{\prime \prime E} 5^{\circ} 7^{\prime} 16^{\prime \prime S}$ & 161,912 & 318,238 & $\begin{array}{l}\text { Coast-Lowland- } \\
\text { Highland }\end{array}$ \\
\hline Urban Takalar Regency & $119^{\circ} 28^{\prime} 34^{\prime \prime E} 5^{\circ} 25^{\prime} 7^{\prime \prime S}$ & 56,651 & 295,892 & $\begin{array}{l}\text { Coast-Lowland- } \\
\text { Highland }\end{array}$ \\
\hline Manggala Urban Area & $119^{\circ} 29^{\prime} 2^{\prime \prime E ~} 5^{\circ} 9^{\prime} 32^{\prime \prime} \mathrm{S}$ & 754.81 & 138,659 & Lowland-Declivous \\
\hline Hertasning-Samata urban area & $119^{\circ} 27^{\prime} 55^{\prime \prime} 5^{\circ} 10^{\prime} 59^{\prime \prime S}$ & 874.02 & 105,839 & Lowland-Declivous \\
\hline $\begin{array}{l}\text { Moncongloe-Pattalassang urban } \\
\text { areas }\end{array}$ & $119^{\circ} 33^{\prime} 28^{\prime \prime E} 5^{\circ} 9^{\prime} 5^{\prime \prime S}$ & $1,038.45$ & 18,784 & Declivous-Hilly \\
\hline Daya urban areas & $119^{\circ} 30^{\prime} 16^{\prime \prime} \mathrm{E} 5^{\circ} 6^{\prime} 17^{\prime \prime S}$ & 441.85 & 16,205 & Lowland-Declivous \\
\hline $\begin{array}{l}\text { Metro Tanjung Bunga urban } \\
\text { areas }\end{array}$ & $119^{\circ} 23^{\prime} 35^{\prime \prime} \mathrm{E}^{\circ} 10^{\prime} 42^{\prime \prime S}$ & $1,275.76$ & 11,952 & $\begin{array}{l}\text { Water's Edge- } \\
\text { Lowland }\end{array}$ \\
\hline Barombong urban areas & $119^{\circ} 23 ' 36^{\prime \prime} \mathrm{E}^{\circ} 12^{\prime} 41 " \mathrm{~S}$ & 533.96 & 13,523 & $\begin{array}{c}\text { Water's Edge- } \\
\text { Lowland }\end{array}$ \\
\hline
\end{tabular}

Source: Author elaboration, Google Map ${ }^{\circledR}, 2019$

The choice of research location is based on several considerations: (i) the reality that develops in the field is plural, (ii) the pattern of population mobility and circular migration between the periphery to the core city is very different depending on the purpose of travel for socioeconomic interests, (iii) the growth of the periphery tends to increase as a result of population mobilisation and land conversion of productive agriculture to highly complex spatial use, (iv) growing urban agglomeration causes spatial interaction to become intensive, and (v) the relationship between spatial integration and spatial interaction has an impact on the growth of Metropolitan Mamminasata urban-suburban areas.

The dynamics of urban growth in the Metropolitan Mamminasata, marked by the conversion of productive agricultural land according to development needs, are characterised by (i) housing and settlements, occupying 2,909.47 ha, (ii) shopping centres - 109.13 ha, (iii) educational facilities - 45.19 ha, (iv) industries - $29.31 \mathrm{ha}$, (v) health facilities - $42.61 \mathrm{ha}$, (vi) tourism and recreational facilities 81.76 ha, and (vii) sports facilities and green open spaces - 189,16 ha. Urban agglomeration and economic growth causes spatial integration, population mobility, circular migration, and spatial interaction, making the core city and periphery behave as a unified urban system. In this study, to facilitate data acquisition, locations were differentiated according to the observed urban status of Metropolitan Mamminasata. The urban status in question is defined by (i) Makassar City as the core city, (ii) Maros City, Sungguminasa City, and Takalar City as supporting cities, and (iii) suburban areas, including urban Daya, urban Manggala, urban Hertasning-Samata, urban Moncongloe-Pattalassang, urban Metro Tanjung Bunga, and urban Barombong.

The data needed to determine the effects of spatial expansion, spatial integration, urban agglomeration, spatial use, and transportation systems on population mobility include (i) spatial expansion, consisting of land use data, spatial distribution patterns, and the Metropolitan Mamminasata urban activity 
system; (ii) spatial integration, including data on spatial linkage patterns, land use integration, facility and infrastructure system integration, infrastructure, and network system integration; (iii) urban agglomeration, including data on urban activities, namely, housing and settlements, industry, shopping centres, and trade and services; (iv) land use change, including data on spatial functions and urban spatial patterns of the Mamminasata Metropolitan; (v) transportation systems, including data on modes of transportation, road functions, traffic volume, and accessibility and transportation facilities and infrastructure; and (vi) population mobility, including data on travel motivations and patterns of origin and destination. The spatial interaction data needed to determine transport system connectivity and growth of suburban areas toward smart and sustainable cities include data on (i) spatial interactions, consisting of data on total population between two cities, the distance between two cities, transportation costs, travel times, flow patterns of goods and services, as well as strength of attraction between the two cities; (ii) connectivity of the transportation system, including data on travel patterns, patterns of transport movement, road functions, travel times, and modes of transportation; (iii) growth of peripheral areas, including data on patterns of socioeconomic activity, sectors of economic activity, and income per capita.

The data collection techniques used in this study are divided into three categories. First, observations of the conditions, characteristics, and urban typologies of Metropolitan Mamminasata were made. Second, the main subjects of this study are population mobility, and spatial interaction, so in-depth interviews were used for two purposes, namely, (i) description and (ii) exploration. In-depth interviews were conducted using tools, namely tape recorders and interview guides, which were equipped with loose notes, checklists, and score scales. The questionnaire in this study was used for two functions: (1) description and (2) measurement. The data traced the purpose and motivation of the trip, educational background, occupation, mode of travel used, transportation costs incurred, and reasons for travel. Third, the documentation included data on the size of the population, obtained from the Statistics Office of South Sulawesi Province; urban spatial patterns and the urban Mamminasata Metropolitan service centre system, obtained from the Spatial Planning Office of South Sulawesi Province; economic growth in urban suburbs, obtained from the Development Planning Agency at Sub-National Level Office South Sulawesi Province, and other documents related to Metropolitan Mamminasata urban development.

A population is a generalisation consisting of objects and subjects that have certain qualities and characteristics; the population of a study is chosen by researchers who then conclude from it (Sugiono, 2016; Creswell, 2016). The population in this study consisted of residents of the Metropolitan Mamminasata. The number of research samples in this study was set at 400 respondents. The sample is determined by a purposive sampling technique according to specific characteristics. The characteristics referred to by the researcher are residents, with a permanent job, married, as well as their travel destination in the study area. 
Table 2. Number of respondents in the Mamminasata Metropolitan Urban study area

\begin{tabular}{llc}
\hline No. & Mamminasata Metropolitan urban area & Number of samples \\
\hline 1 & Makassar City & 68 \\
2 & Urban Gowa Regency & 50 \\
3 & Urban Maros Regency & 40 \\
4 & Urban Takalar Regency & 35 \\
5 & Manggala Urban Area & 35 \\
6 & Hertasning-Samata Urban Area & 30 \\
7 & Moncongloe-Pattalassang Urban Area & 30 \\
8 & Daya Urban Area & 40 \\
\hline
\end{tabular}

Source: BPS South Sulawesi Province, 2019 and author elaboration

These characteristics were used by researchers in determining respondents (Table 2). Sampling refers to Cochran (1991).

$$
n=\frac{N}{N \mathrm{~d}^{2}+1}
$$

where, $n$ refers to the sample size, $N$ refers to the population size, and d refers to the error rate $(0.5)$ or $5 \%$ of the $95 \%$ confidence level.

The analytical method used in this study is divided into two main categories, namely, (i) qualitative analysis, used to interpret population mobility, circular migration, and orientation of population activities from the origin to the destination, and (ii) quantitative analysis, used to answer research objectives regarding the relationship of spatial expansion $\left(\mathrm{X}_{1}\right)$, spatial integration $\left(\mathrm{X}_{2}\right)$, spatial interaction $\left(\mathrm{X}_{3}\right)$, urban agglomeration $\left(\mathrm{X}_{4}\right)$, space utilisation $\left(\mathrm{X}_{5}\right)$, and the transportation system $\left(\mathrm{X}_{6}\right)$ with population mobility $(\mathrm{Y})$. For each question, respondents answered on a numerical scale with 5 as the highest score. The second step was implemented by dividing the results of the research scores by ideal scores. The correlation coefficient between variables was tested using the regression method with the following equation:

$$
\mathrm{Y}=\mathrm{a}+\mathrm{b}_{1} \mathrm{X}_{1}+\mathrm{b}_{2} \mathrm{X}_{2}+\mathrm{b}_{3} \mathrm{X}_{3}+\ldots+\mathrm{b}_{\mathrm{n}} \mathrm{X}_{\mathrm{n}}
$$

where $\mathrm{Y}$ is the dependent variable, $\mathrm{X}$ is the independent variable, $\mathrm{a}$ is a constant, and $b_{1}, b_{2}$, and $b_{3}$ are regression coefficients. The correlation coefficient test used the Pearson correlation coefficient. Consideration was given to two criteria: (i) the characteristics of the research data are interval-scale data, and (ii) the correlation between two or more variables is linear, meaning that the distribution of the data obtained shows a direct relationship: 


$$
r=\frac{\sum X Y \frac{\sum X \sum Y}{n}}{\sqrt{\sum X^{2}-\frac{\left(\sum X\right)}{n}\left(\sum Y^{2}-\frac{(\Sigma Y)}{n}\right.}}
$$

where, $\mathrm{r}$ is the value of the correlation coefficient, $\mathrm{X}$ is the number of observations of variable $\mathrm{X}, \mathrm{Y}$ is the number of observations of variable $\mathrm{Y}, \sum \mathrm{XY}$ is the result of multiplying variables $\mathrm{X}$ and $\mathrm{Y}, \sum \mathrm{X}^{2}$ is the sum of squares of the observations of variable $\mathrm{X}, \sum \mathrm{Y}^{2}$ the sum of squares from observations of variable $\mathrm{Y}$, and $\mathrm{n}$ is the number of observation pairs $\mathrm{X}$ and $\mathrm{Y}$.

To achieve the research objectives, the two analytical methods used are spatial interaction models. The aim is to explain the distribution and spatial pattern of movement from the core city to the Metropolitan suburb of Mamminasata. Spatial interaction models are usually the first two steps in the standard four-step transportation/land use model, as they estimate the spatial generation and distribution of trips (Bintarto, 1984).

Spatial interactions in this study were used to reach three main goals, namely, (i) to get an idea of the spatial influence of relations between inhabitants as well as between inhabitants and their environment, (ii) to define the spatial interactions of the core city and periphery areas related to population flows, material, information, and energy, and (iii) to explain the features of location, relocation, distribution, and diffusion. In the economic relationship between two places as a whole metropolitan, the urban system is characterised by Carothers's theory as the strength of economic relations between two places being directly proportional to the size of the population and indirectly proportional to the distance between them. That is, the greater the population in two places, the greater the economic interaction, but the further the distance between them, the smaller the interaction is.

Considerations and references used in measuring the interaction of spatial cities of the core and periphery areas as an integrated Metropolitan Mamminasata urban system were (i) higher-order functions of the city, (ii) the wider interaction area, (ii) barriers and inhibitors of producers and consumers, predominantly the distance factor, (iii) the variation of the assessment used ranges from 0.4 to 3.3, based on the topographic conditions and geographical barriers, and (iv) the potential and magnitude of the influence of the core city of Makassar on the Metropolitan suburban area of Mamminasata. The stopping point is measured based on the boundary line that separates the trade area between the core city and the supporting cities and between the urban suburbs of the Metropolitan Mamminasata, and the amount of service is different for each urban area. Furthermore, the level of accessibility is measured through several variables: availability of the road network, modes of transportation, road length, road width, and road quality. Newton's law of gravity was applied to analyse population mobility and spatial interaction problems: 


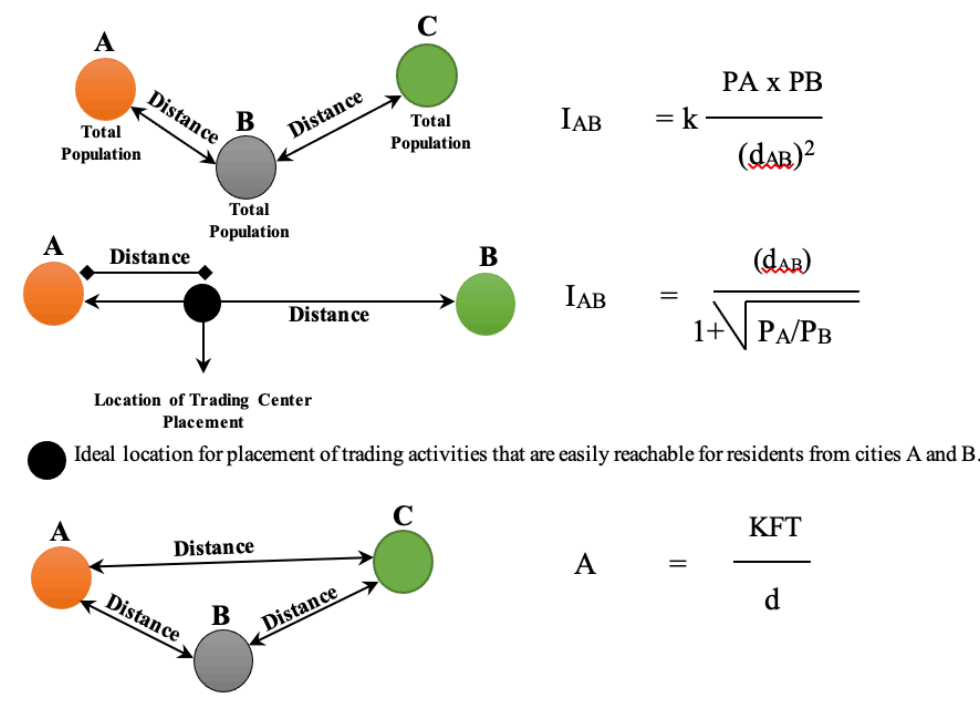

In the analytical formulation used, the following definitions apply: (i) $I_{B}$ is a business index calculated from the population of two cities. $\mathrm{P}_{\mathrm{A}}$ and $\mathrm{P}_{\mathrm{B}}$ are representations of the larger population of city $A$ and the smaller population of city $B$, and $d$ is the distance between two cities $(\mathrm{km})$; (ii) $I_{A B}$ is the strength of the interaction between regions $\mathrm{A}$ and $\mathrm{B}, \mathrm{k}$ is an empirical constant with a value of 1 , $P_{A}$ is the population of area $A$, and $P_{B}$ is the population of area $B$, while $d_{A B}$ is the distance between regions $A$ and $B(k m)$; (iii) $D_{A B}$ is the point location stops measured by cities/regions with smaller populations (in this case, city $A$ ), $d_{A B}$ is the distance between city $A$ and city $B(\mathrm{~km}), P_{A}$ is the larger population of city $A$, and $P_{B}$ is the smaller population of city $B$ (soul); and (iv) $A$ is the value of accessibility, $\mathrm{K}$ is the average number of trips of the population, $\mathrm{F}$ is a road function (primary $=3$, secondary $=2$, and local $=1$ ), $\mathrm{T}$ is road conditions $(\operatorname{good}=3$, medium $=2$, $\mathrm{bad}=1)$, and $\mathrm{d}$ is the distance between two cities $(\mathrm{km})$. The research analysis framework is shown in Figure 1.

\section{Results}

The spatial expansion of Makassar's core city in the Metropolitan Mamminasata urban system has resulted in land-use changes toward very complex spatial use. Spatial patterns with social dynamics produce elements of both fixity and mobility in complex developing systems in which material reality and imaginative possibilities of city life are produced (Healey, 2007). Furthermore, peri-urban areas can be seen not only as a suburb between cities and villages, a transition zone but also as a new multi-functional area that shows the relationship of spatial links between the city centre and the periphery (Ravetz et al., 2013; Surya, 2015). Excessive urbanisation and maximum compaction of the core city of Makassar have led to the conversion of productive agricultural land to highly complex spaces in suburban areas. 


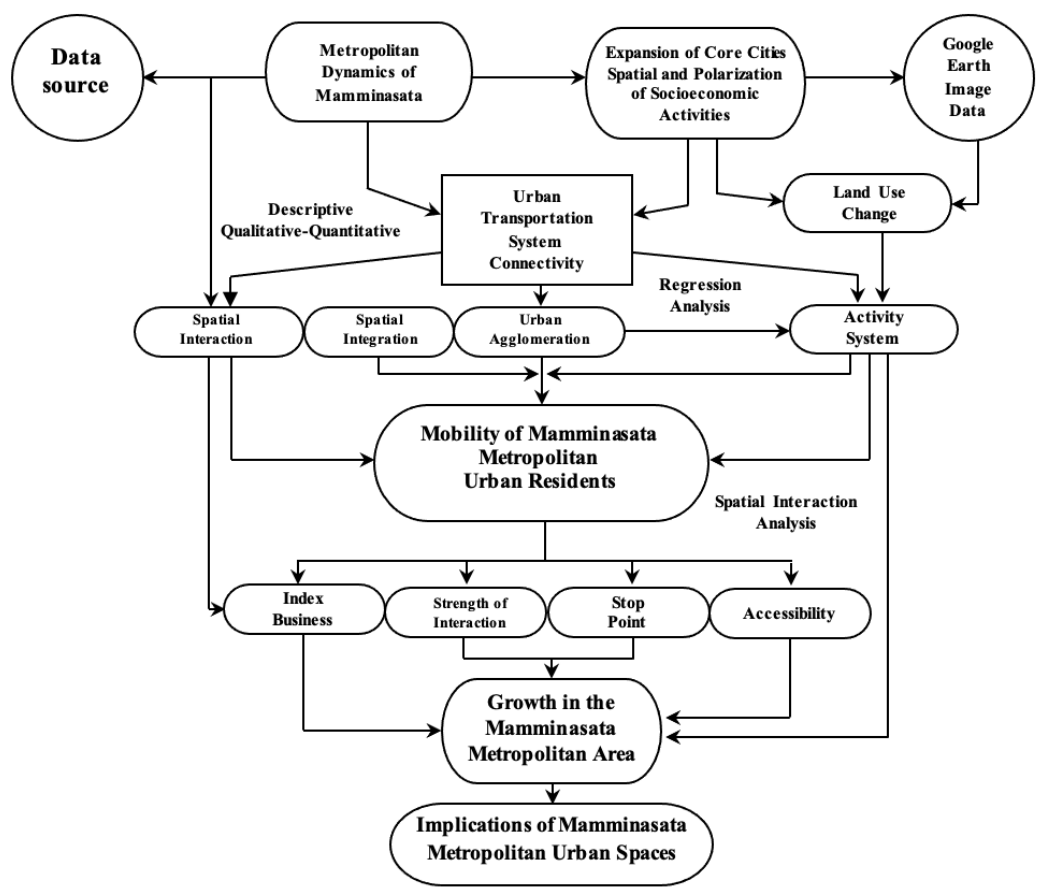

Figure 1. Analysis of process flow, spatial integration, spatial interaction, urban agglomeration, and the Mamminasata Metropolitan urban activity system

The impact of the initial process of urbanisation and the rapid development of metropolitan cities affects the development of spatial planning, urban climate, and also causes changes in the spatial structure and spatial patterns of metropolitan cities (Surya, 2016; Jiang et al., 2018). The utilisation of space in the outskirts of the Mamminasata Metropolitan area is shown in Table 3.

Table 3. Spatial Use of Mamminasata Metropolitan urban suburbs

\begin{tabular}{lcccccc}
\hline \multicolumn{1}{c}{$\begin{array}{c}\text { Space utilisation } \\
\text { (ha) }\end{array}$} & \multicolumn{5}{c}{ Mamminasata Metropolitan urban suburbs } \\
\cline { 2 - 7 } & Daya & Manggala & $\begin{array}{c}\text { Hertasning- } \\
\text { Samata }\end{array}$ & $\begin{array}{c}\text { Moncongloe- } \\
\text { Pattalassang }\end{array}$ & $\begin{array}{c}\text { Metro Tanjung } \\
\text { Bunga }\end{array}$ & Barombong \\
\hline Settlement & 251.3 & 486.66 & 770.23 & 266.32 & 877.08 & 257.88 \\
Office space & 15.09 & 9.88 & 3.55 & 4.25 & 8.23 & 3.65 \\
Shopping center & 45.85 & 22.77 & 21.03 & 0.96 & 14.29 & 4.23 \\
Recreational & 2.65 & 14.68 & 14.55 & - & 25.68 & 24.2 \\
facilities & & & & & & 13.05 \\
Traditional market & 12.36 & 4.33 & 8.89 & 2.45 & 9.91 & 14.08 \\
Education facility & 8.51 & 7.48 & 7.06 & 4.88 & 8.66 & 4.55 \\
Health facility & 10.02 & 9.22 & 4.5 & 5.66 & 12.68 & 6.99 \\
Sports field & 9.95 & 4.04 & 6.33 & 2.08 & 26.28 & 7.88 \\
Green open space & 23.12 & 13.66 & 7.23 & 68.92 & 125.02 & 147.52 \\
Rice fields & 20.06 & 122.44 & 4.21 & 387.5 & 56.32 & 45.78 \\
Plantation & $\mathbf{1 4 . 2 8}$ & 40.88 & 26.44 & 288.03 & 98.56 & 9.85 \\
Pond & 8.11 & 10.89 & - & 6.52 & - & - \\
Industry & 20.55 & 7.88 & - & 0.88 & $\mathbf{1 . 2 7 5 . 7 6}$ & $\mathbf{5 3 3 . 9 6}$ \\
Total & $\mathbf{4 4 1 . 8 5}$ & $\mathbf{7 5 4 . 8 1}$ & $\mathbf{8 7 4 . 0 2}$ & $\mathbf{1 . 0 3 8 . 4 5}$ &
\end{tabular}

Source: Author elaboration; Google Map@, 2019; BPS South Sulawesi Province, 2019 
The accelerated urban development of the Mamminasata Metropolitan (Table 3) due to suburbanisation and population migration has resulted in the conversion of productive agricultural land, changes in people's lifestyles, and the diffusion of spatial areas. Urbanisation is a spatial process: in an early phase, the geographical distribution of the population gradually concentrates in cities, while at a later stage, urban lifestyles and infrastructure diffuse to the countryside (Kurek et al., 2015). The conversion of agricultural land, marked by the allocation of dominant residential space use, occupies an area of 2,909.47 hectares or $55.10 \%$ of the total area of the periphery. Furthermore, the non-dominant use of space is occupied by industry, with an area of 29.31 hectares. Transfer of land use functions that are dominant in the preparation of housing and settlements is positively associated with infrastructure development and urban transportation systems. Infrastructure connectivity and transportation systems have an impact on urban agglomeration and urban sprawl along main road corridors. Spatial structure and urban agglomeration are essential factors influencing regional functions and sustainable development (Fan et al., 2018).

Furthermore, urban integration has resulted in the continued compression and fragmentation of ecological space (Abshirini and Koch, 2016; Hesse and Siedentop, 2018). Changes in spatial use due to an increase in population causes spatial integration and urban agglomeration, resulting in spatial interactions and patterns of distribution of goods and services. Therefore, spatial interaction between urban clusters must be considered in future regional planning. The spatial pattern and evolution of urban systems will intuitively help explain the evolution mechanism of urban systems (Vijayakumar, 2013). The formation of an urban agglomeration is not only connected to the geographical location and distribution of the city but also relevant to the economy and social culture (Rosado \& Alvarado, 2017). Changes in spatial use that tend to be revolutionary cause changes in typology and morphology toward spatial polarization and community segmentation in the suburban metropolitan urban areas of Mamminasata. Suburbia-that vast and aimless drift of human beings, spreading in every direction about our cities, large and small-demonstrates the incapacity of our civilization to foster concrete ways and means for living well (Geurs \& Wee, 2004).

The increase in urban activity is in line with the increase in population (Figure 2). With regard to the six locations of the periphery area, the highest population is located in the periphery of Manggala or 138,659 inhabitants. The lowest population is located in the suburb of Barombong, or 13,523 inhabitants. Furthermore, as many as 7,721 people are categorised as non-productive age (04 years), 14,156 people are of productive age groups (15-64 years), and 6,435 people are already in the unproductive age population $(65+$ years). This figure confirms that, in general, the Metropolitan Mamminasata urban areas have entered the era of demographic bonuses; that is, the population of productive age is more dominant than that of the non-productive age. Population changes can have a powerful impact on economic growth, and stable economic growth has a relationship with increased labour productivity and labour-intensive technology (Couclelis, 2000; Lee \& Kim, 2017). 

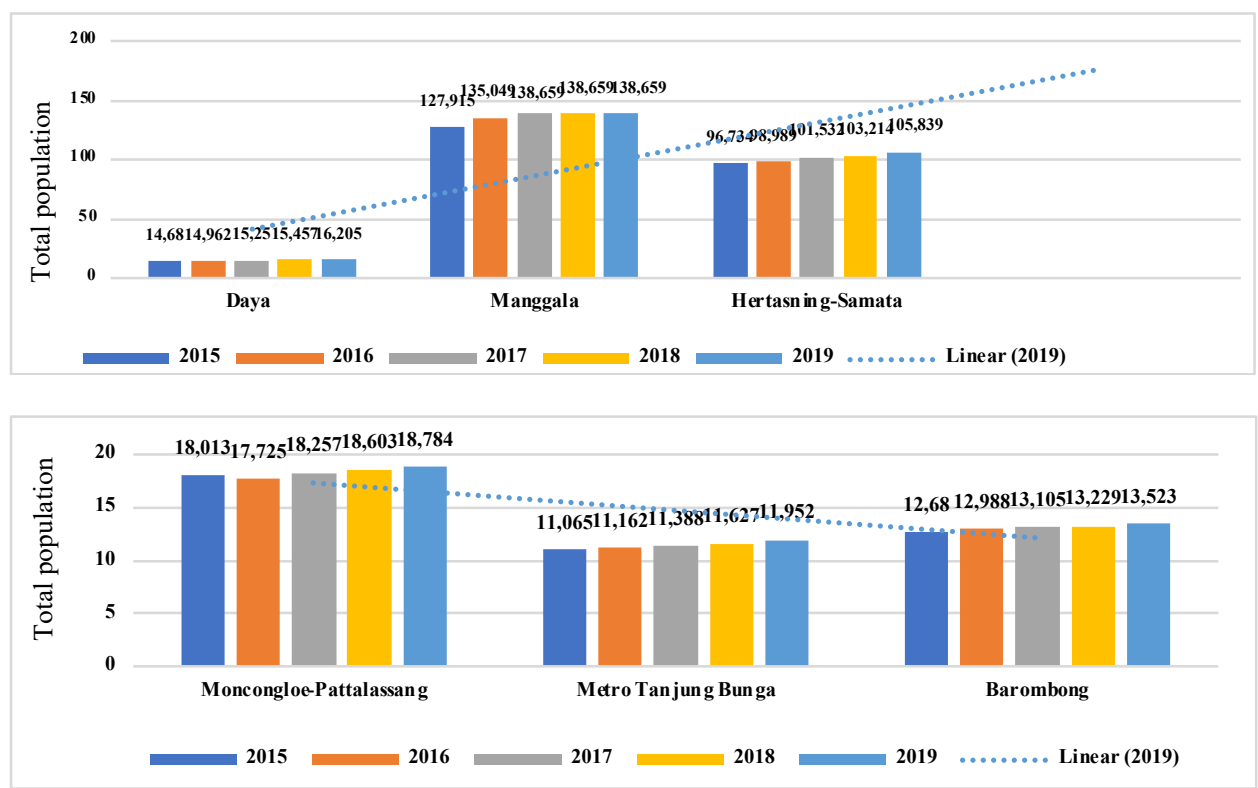

Figure 2. Total population in Mamminasata Metropolitan area in 2015-2019.

Source: BPS South Sulawesi Province, 2019

An increase in population coupled with economic growth will require the availability of jobs, the mastery of technology, and expertise and adequate skills, especially for the productive age population.

Mobility of the urban population of Metropolitan Mamminasata does not occur by itself but is influenced by several factors. The first is accessibility between regions, between cities, and between urban areas. In this case, accessibility is very much related to the support of transportation facilities and infrastructure that facilitate accessibility from the area of origin to the destination. Advanced accessibility measures point toward including an individual's spatial-temporal constraints and feedback mechanisms between accessibility, land-use change, and travel behaviour (Pinto, 2002). Furthermore, this development is combined with advances in the design and management of physical transport to create a landscape shape of accessibility that changes substantially and reflects profound changes in the meaning of the term itself and its implications for urban and regional structures and functions (Wrede, 2001). Second, dominant employment opportunities are available in the core city. In this case, urban activities tend to be located in the centre of Makassar City, including industry, ports, airports, shopping centres, and other economic activities. The existence of these activities becomes a motor for population mobility, circular migration, and opportunities for residents from rural areas to grab opportunities for work and business and prosperity. The success of this relocation as a population distribution tool depends very much on the role of the government and family, as well as financial facilities (Starkey \& Hine, 2014). Furthermore, migration depends on the relocation decision between the two regions (Chen et al., 2020). The third factor 
is the quality of life and a pleasant environment. In this case, there is an accumulation of various facilities available in Makassar City, including educational facilities, health facilities, and public facilities. The support of adequate transportation facilities and infrastructure has caused the intensity of population mobility from the periphery to the core city to be quite high. Investment in urban and rural roads stimulates economic and social growth development (Liu et al., 2019). Fourth, the existence of entertainment centres and cultural centres in the core city of Makassar impacts the desire of migrants to reside in the city centre. Public spaces and road environments, as well as various service facilities, many of which are in a low economic order, attract people from all major cities, which hold more than ten million, highlighting a new role for the CBD as a civic centre (Kordes et al., 2020). These four factors cause population mobility and circular migration to the core city to be relatively high, and the driving force is the position of Makassar City as the primary city in the Metropolitan Mamminasata urban system as the leading service centre in Eastern Indonesia.

The determining factor for population mobility is connectivity between the city centre and the periphery. Mobility has always been an important driving force for rural changes, which can be found in population flows and other factors between urban and rural areas (Brandl \& Zielinska, 2020). Interpretations that can be proposed are related to the process of population mobility and circular migration. First, land ownership, in this case, the limitations of wealth, is positively associated to land status. Results show that from $2.9 \%$ to $11.4 \%$ of the population left their home area to go to the core city of Makassar to find work to support their family's needs and because of their inability to own land in their home area. The concept of migration management suggests that if migration processes are managed strategically, it benefits all parties involved (Kuchiki, 2020).

Second, the existence of industries, shopping centres, shops, and other economic activities that are dominantly developing in the core city provide opportunities for residents to get decent jobs and improve their quality of life. Work is not only an integral part of one's income but also one's identity and psychosocial well-being, as well as being important for peace and social cohesion, and must therefore be the heart of a social-ecological transformative strategy (Mouzughi et al., 2014). Results found that from $24.3 \%$ to $38.6 \%$ of population mobility to Makassar City is to get work. Field observations illustrate that the circular migration from the periphery to the core city is quite high in intensity. Furthermore, the dominant economic agglomeration develops into opportunities for residents and circular migration to develop businesses and for construction workers to gain economic benefits. Economies of sequence can be defined as the sequencing of segments toward the efficient building of an agglomeration (Twumasi et al., 2020).

Third, the income level is a condition triggered by the existence of centres of economic activity and large-scale settlement development. Migrant groups are considered to be potential sources for developing businesses and trade in terms of meeting basic needs for consumers in the core city. The construction of real estate has the potential to advance sustainability in terms of meeting economic 
and social criteria (Chen et al., 2016). Results show that $18.6 \%$ to $24.3 \%$ of the fulfilment of the community's basic needs in the core city was met by the circular migration group in the supply of daily necessities. In this context, the results illustrate that circular migration positively contributes to meeting the needs of consumers in the city of Makassar. Migration goals ensure the effective functioning of family units and enable them to become productive members of their local communities (Horak et al., 2019).

Fourth, the Metropolitan Mamminasata urban transportation network system, which is supported by a main road corridor, increases the ease of mobility and shortens travel times. Household mobility is seen mainly among large cities, with movement toward nearby cities. Furthermore, employment, income, residence time, and schools significantly impact households (Vidovic et al., 2020). Field data show that $11.4 \%-18.6 \%$ of population mobility and circular migration from the periphery to the core city use the main road corridor. This means that distance factors determine the increase in population mobility, the transportation movement system, and the urban agglomeration of Metropolitan Mamminasata. Increasing traffic is an inherent symptom of vigorous urban development and its prosperity. However, it is concurrently one of the main factors contributing to the deterioration of the urban environment and endangers the sustainability of urban development (Zhang et al., 2019). Furthermore, the urban population's sustainable mobility is an essential and integral part of social and economic life, affecting the economy and quality of life, especially in large agglomerations (Luiu et al., 2018).

The fifth factor is the consideration of transportation costs. Transportation costs are significant in choosing transportation modes for mobility purposes from the area of origin to the destination. An effective way to optimise traffic structures is to change travel costs so that they encourage travellers to move from private vehicles to public transportation (Liu et al., 2019). Results show that 10.0\%-24.3\% of the population incurred transportation costs for travel to Makassar. The results of the field confirmation illustrate the variation and differences in transportation costs incurred for travel needs depending on the choice of transportation mode. Furthermore, variations in the choice of transportation modes are strongly related to population welfare. The dominant mode of transportation used is twowheeled vehicles. These conditions increase the volume of traffic and traffic congestion in the main corridor of the Metropolitan Mamminasata urban road. Segmentation of people's mobility tends to vary but is usually associated with attitudes toward modes of transportation and level of mobility (Jing et al., 2018). The cost has a significant effect on short-distance travel modes, and waiting time is considered the most crucial factor in the short-range scenario, and the transfer time is regarded as the most significant in the medium- and long- distance scenarios (Wenner et al., 2020). Furthermore, traffic congestion is becoming increasingly severe, which is unavoidable because traffic demand exceeds traffic supply and has become a critical problem that must be immediately resolved in most major cities of the world (Wen et al., 2019). 
Sixth, accessibility is the ease of travelling from the periphery to the core city. Transport accessibility is one of the most significant location factors for both households and firms, and is a driver of urban development (Nugmanova et al., 2019). Results show that this factor triggers $8.6 \%$ to $17.1 \%$ of population mobility and circular migration toward the Makassar City. The results of the field confirmation illustrate that the connectivity of the transportation system between the periphery and the core city, as well as the support of the main road corridor as a means of mobility and infrastructure used by residents to travel, is positively associated with an increase in traffic volume and traffic congestion during rush hour, i.e. in the morning and afternoon. Traffic congestion is one of the most vexing city problems and involves numerous factors that cannot be addressed without a holistic approach (Liu et al., 2019). Furthermore, to increase road capacity and reduce traffic congestion, ring roads can be built, although this often proves ineffective in the long run (Cao et al., 2017). Population mobility and circular migration illustrate that the accumulation of various urban activities, specifically industrial and trade activities, impacts increasing daily traffic volume. As a result, comfort and travel time to get to work and other activities become disrupted. The urban transportation system should meet the requirements of various social groups and be fair and comprehensive (Park et al., 2018). Furthermore, urban travel requires higher levels of sustainable urban transport (Hong et al., 2020). Thus, population mobility and circular migration from the suburban Metropolitan Mamminasata urban area to the core city of Makassar are inefficient and ineffective. Traffic volume that continues to increase in the main road corridor from the periphery to the core city has a direct impact on road capacity, economic costs, the comfort of travel, and travel time to the destination. Therefore, it is imperative to improve the Mamminasata Metropolitan urban transportation system in the future; in this case, it is necessary to integrate the system and management of transportation to reduce congestion, shorten travel time, use mass transportation, and develop road network systems to move toward the sustainability of the metropolitan urban transport system. Sustainable transportation is an essential part of a sustainable city; however, modern transportation systems with internal-combustion engines emit unacceptably high levels of air pollutants and noise (Lim \& Kim, 2018).

The six aspects examined show that limited land ownership, dominant employment opportunities in the core city, income level, distance travelled, transportation costs and accessibility positively contribute to population mobility and circular migration and their impact on traffic congestion on the main road corridor. Specifically, commuting pattern recognition is a key step for some applications, such as congestion pricing and active traffic management (Girard \& Nocca, 2019). Motivation and travel destinations generally link population mobility and circular migration from the periphery toward Makassar City in the study area. Decisions to travel are based on destination orientation, including interests such as social and economic factors and transportation modes used, as well as supporting facilities and infrastructure that are utilized (Figure 3). 


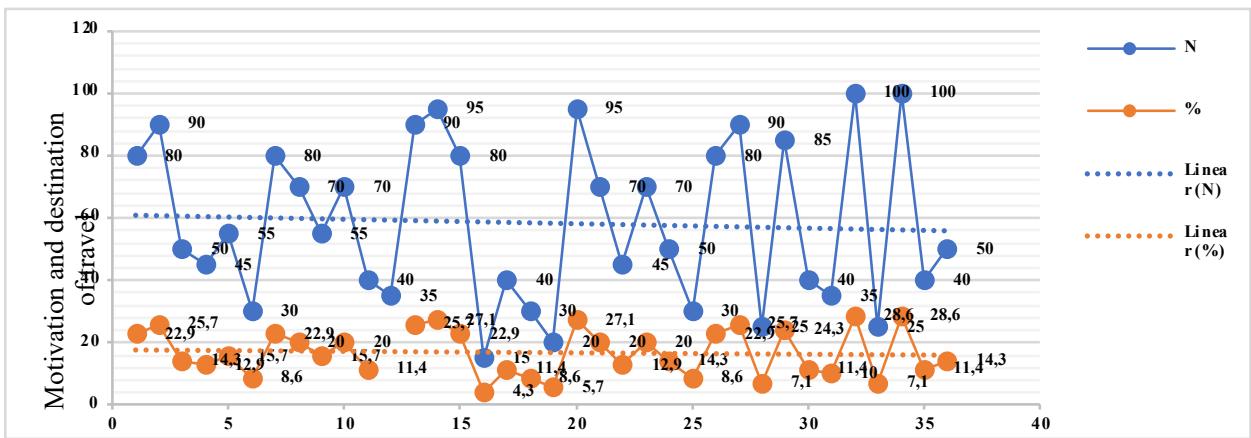

Figure 3. Motivation and travel destinations of the Mamminasata Metropolitan urban suburbs. Source: Primary Data, 2020.

The orientation of the population's travel destination (Figure 3), based on mobility and circular migration patterns in the context of core-periphery relations in the Metropolitan Mamminasata urban system, is very complex in terms of its impacts. Relocation-commuter associations were found to differ substantially by region, indicating the importance of regional-specific factors in forming relationships (Hyoung \& Gim, 2018). Furthermore, the disparity in the services of urban activities between the periphery and the core city shows fundamental differences in economic circulation, social disparity, and ecosystem characteristics.

Thus, circular economic models can be applied in cities to operationalise and manage sustainable human development simultaneously from a systemic perspective involving problems of social inequality and ecological and economic crises (Chen et al., 2019). Interpretations are related to the purpose of travel from the periphery to the core city, namely: (i) for educational purposes contributed an average of $14.5 \%$ of traffic generated due to the concentration of educational activities in the core city; (ii) for work purposes contributed an average of $21.9 \%$ of traffic generated; (iii) for business purposes contributed an average of $17.6 \%$ of generated traffic; (iv) for building social relations contributed an average of $14.3 \%$ of generated traffic; (v) for building business relationships contributed an average of $15.7 \%$ of generated traffic; and (vi) trips for tourism/recreation interests contributed an average of $11.2 \%$ of traffic generation.

Compact land use has stronger effects, and the effects of internal travel and external travel reduction are weaker; that is, there is a change in the destination rather than in total travel time (Hoang et al., 2019). In addition, commute-related trips represent the regular flow between housing and business areas, and leisurebased trips during holidays are often stochastic movements. Regional-oriented demand strategies can efficiently reduce traffic congestion (Wu et al., 2016). Spatial expansion, spatial integration, spatial interaction, urban agglomeration, spatial use, and transportation systems together have a significant effect on population mobility in the Mamminasata Metropolitan urban suburbs (Table 4). 
Table 4. Summary of results of associative hypothesis testing

\begin{tabular}{lcccc}
\hline Correlated Variables & R-table T-table & t count & Sig. \\
\hline Spatial Expansion to Population Mobility $\left(\mathrm{ryx}_{1}\right)$ & 0.26 & 1.67 & 4.907 & .000 \\
Spatial Integration to Population Mobility $\left(\mathrm{ryx}_{2}\right)$ & 0.26 & 1.67 & 2.987 & .004 \\
Spatial Interaction to Population Mobility $\left(\mathrm{ryx}_{3}\right)$ & 0.26 & 1.67 & 4.870 & .000 \\
Urban Agglomeration to Population Mobility $\left(\mathrm{ryx}_{4}\right)$ & 0.26 & 1.67 & 2.096 & .041 \\
Utilization of Space to Population Mobility $\left(\mathrm{ryx}_{5}\right)$ & 0.26 & 1.67 & 2.643 & .011 \\
Transportation Systems to Population Mobility $\left(\mathrm{ryx}_{6}\right)$ & 0.26 & 1.67 & 5.154 & .000 \\
Spatial Expansion, Spatial Integration, Spatial Interaction, & \multirow{2}{*}{ F count $=\mathbf{7 4 . 4 3 6}>\mathbf{F}$ table $=\mathbf{2 . 2 5 0}$} \\
Urban Agglomeration, Spatial Use, and Transportation & & & & \\
Systems Together vs. Population Mobility $(\mathrm{R})$ & & & &
\end{tabular}

Metropolitan Mamminasata urban connectivity is facilitated by the existence of the main road corridor that connects the periphery to the core city of Makassar. Accessibility also seems to vary greatly across cities: the population living in the central district enjoys better accessibility compared with those in the periphery environment (Wagistina \& Wahab, 2019). The results of the regression analysis confirm that the periphery, which was initially difficult to reach in terms of the distribution of the flow of goods and services, subsequently underwent significant changes due to the expansion of the core city space. These results confirm that the expansion of the core city causes the circle of the Mamminasata Metropolitan urban system to move toward the complexity of spatial use, urban agglomeration, and the formation of spatial activity systems. Furthermore, the connectivity of the urban transportation system is positively associated with population mobility. That is, the stronger the attraction of the core city, the greater the flow of movement and mobility of the population toward the interplay of mutual influence and dependence between urban space components. The results show patterns of relationships between natural factors, natural factors with humans, nature and sociocultural conditions, and socioeconomic factors. Increased accessibility is concentrated not only between large cities but also in all suburban cities. With the advantage of comparative market access, intense traffic flow can also increase the productivity of second- and third-tier cities (Han \& Liu, 2018).

\section{Discussions}

The spatial interaction between the core city and the suburban area of the Metropolitan Mamminasata is influenced by several factors: (i) suburbanisation, population mobilization, and circular migration, (ii) distribution of the flow of goods and services, and (iii) connectivity of the transportation network system. Field data show that four things cause the intensity of the Mamminasata Metropolitan urban spatial interaction, namely, (a) the centralisation of activities in the core city and the needs of workers that can be met by the periphery, (b) patterns of population mobility from the area of origin to destinations for social, economic, and cultural interests, (c) the modes of transportation and the support of main road corridors for ease of transferability and the increasingly intensive flow of goods and people, and (d) increased economic circulation from the core 
city toward the periphery. Thus, the spatial, economic, and social interactions between the core city and the suburbs are reciprocal and mutually beneficial.

The spatial interaction of the core city and the outskirts of the Mamminasata Metropolitan area tends to reflect a reciprocal relationship based on proximity factors, location factors, and urban service systems. Field data show that spatial integration and growing urban agglomeration impact the intensity of the interaction. Urban spatial interactions are important for optimizing the spatial structure and spatial layout of urban agglomeration (Alverti et al., 2020). The strengths of the spatial interaction are strongly influenced by several factors, namely, (i) the complementary relationship between the core city and the periphery, (ii) the opportunity to intervene in the distribution of goods and services as well as the opportunity for socioeconomic activities that tend to expand toward the periphery, and (iii) spatial diffusion due to the support of the transportation system and urban infrastructure. The movements of passengers or freight from an origin to a destination rely on several modes of transportation barriers that affect the use of public transportation are grouped into six main categories: (1) Reliability and availability of service provision; (2) Health and mobility problems; (3) comfort; (4) Personal security; (5) Information and awareness; and (6) Affordability. The spatial interaction of the core city and the suburban, urban area of Mamminasata Metropolitan is shown in Figure 5.

Metropolitan Mamminasata urban spatial interactions (Figure 4) are influenced by three main factors: (i) socio-economic conditions, population mobility, and circular migration based on shared travel interests, (ii) topographic conditions, and (iii) support of urban transport systems, which serves to connect the core city, supporting cities, and suburbs. The effect of urban facilities differs between categories and sub-markets, and the effect of irreplaceable facilities is very dependent on accessibility in all sub-markets, while the effect of replaceable facilities depends on the accessibility and scarcity of these facilities (Xia et al., 2020).

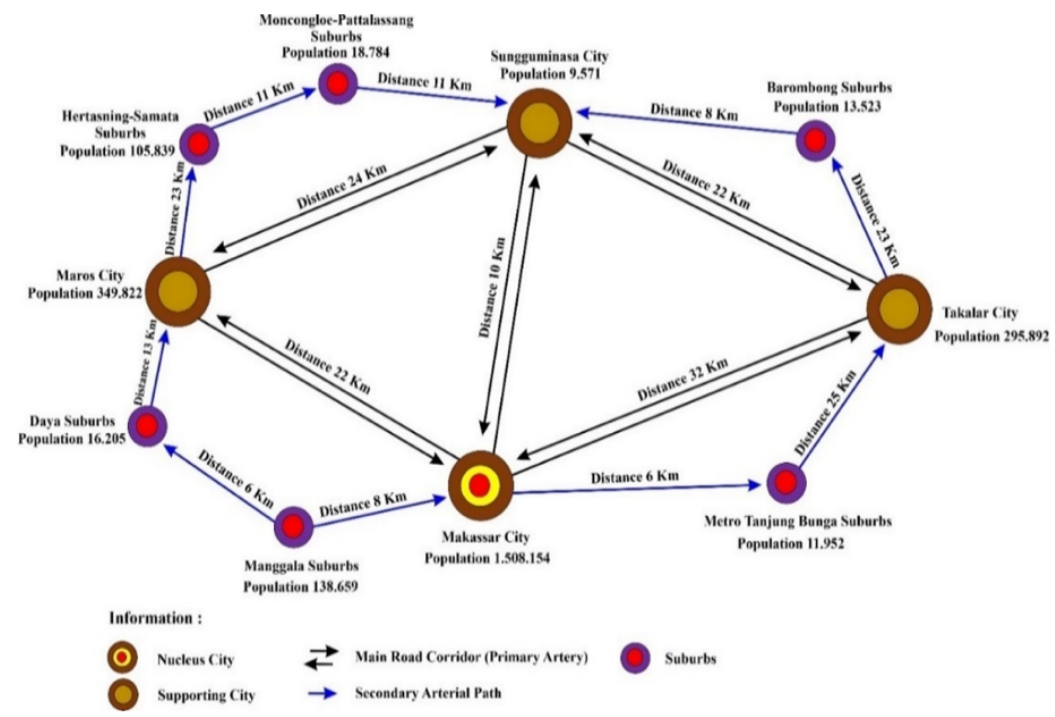

Figure 4. Example of Mamminasata Metropolitan spatial urban interaction 
The intensity of spatial interaction in periphery areas is generally influenced by the intensity of movement and the function of socioeconomic activities (Table 5). Theoretically, the spatial interaction of the core cities and supporting cities in the Mamminasata Metropolitan urban system is divided into four main categories, namely: (1) Makassar as a core city interacts with Maros with a strength of attraction of 4,3; (2) Makassar City interacts with Sungguminasa City with a strength of attraction of 158; (3) Makassar City interacts with Takalar City with a strength of attraction of 5,10 . These results confirm that the spatial interaction of Makassar City with Sungguminasa City of Gowa Regency is much higher or stronger when compared with Maros City and Takalar City. Determinants of factors that influence these conditions are closer distances, greater population size, population mobility, and more dominant circular migration. This fact confirms that the spatial expansion of the core city of Makassar is more dominant toward the urban area of Sungguminasa City.

The pattern of spatial activities that develops is obtained by a picture of the business relationship between the core and supporting cities in the Mamminasata Metropolitan urban system, namely:

Table 5. Spatial interaction of core city, supporting city, and suburban area of Mamminasata Metropolitan

\begin{tabular}{|c|c|c|c|c|c|c|}
\hline Mamminasata Metropolitan Suburbs & $\begin{array}{l}\text { Business } \\
\text { index }\end{array}$ & $\begin{array}{l}\text { Strength } \\
\text { of } \\
\text { attraction }\end{array}$ & Weight & $\begin{array}{l}\text { Magnitude } \\
\text { of } \\
\text { interaction }\end{array}$ & Accessibility & $\begin{array}{l}\text { Stop } \\
\text { point } \\
(\mathrm{km})\end{array}$ \\
\hline Makassar City to Maros City & 20,291 & 4.3 & 0.4 & 23,981 & 0.82 & 22.48 \\
\hline Makassar City to Sungguminasa City & 1,974 & 158 & 0.4 & 1,443 & 1.2 & 10.08 \\
\hline Makassar City to Takalar City & 14,465 & 5.10 & 0.4 & 13,945 & 0.37 & 32.44 \\
\hline Makassar City to Manggala suburb & 28,221 & 10.88 & 0.4 & 26,139 & 1.5 & 8.30 \\
\hline Makassar City to Daya suburb & 2,221 & 93.07 & 0.4 & 1,745 & 1.28 & 14.1 \\
\hline $\begin{array}{l}\text { Makassar City to Hertasning-Samata } \\
\text { suburb }\end{array}$ & 18,779 & 14.25 & 0.4 & 13,301 & 1 & 12.26 \\
\hline $\begin{array}{l}\text { Makassar City to Moncongloe- } \\
\text { Pattalassang suburb }\end{array}$ & 1,518 & 80.29 & 0.4 & 1,349 & 0.57 & 21.35 \\
\hline $\begin{array}{l}\text { Makassar City to Metro Tanjung } \\
\text { Bunga suburb }\end{array}$ & 3,004 & 126 & 0.4 & 3,004 & 2 & 6.09 \\
\hline Makassar City to Barombong suburb & 1,669 & 111 & 0.4 & 2,266 & 1.33 & 19.56 \\
\hline Maros City to Daya suburb & 283 & 21.59 & 0.4 & 436 & 1.38 & 17.65 \\
\hline $\begin{array}{l}\text { Maros City to Hertasning-Samata } \\
\text { suburb }\end{array}$ & 1,276 & 3.3 & 0.4 & 1,609 & 0.52 & 23.55 \\
\hline $\begin{array}{l}\text { Maros City to Moncongloe- } \\
\text { Pattalassang suburb }\end{array}$ & 219 & 18.62 & 0.4 & 193 & 0.35 & 32.23 \\
\hline $\begin{array}{l}\text { Sungguminasa City to Moncongloe- } \\
\text { Pattalassang suburb }\end{array}$ & 8 & 1.96 & 0.4 & 16 & 1.09 & 12.4 \\
\hline $\begin{array}{l}\text { Sungguminasa City to Hertasning- } \\
\text { Samata suburb }\end{array}$ & 253 & 11 & 0.4 & 126 & 1.5 & 11.32 \\
\hline $\begin{array}{l}\text { Sungguminasa City to Barombong } \\
\text { suburb }\end{array}$ & 16 & 1.41 & 0.4 & 16 & 1.5 & 9.19 \\
\hline $\begin{array}{l}\text { Takalar City to Metro Tanjung } \\
\text { Bunga suburb }\end{array}$ & 126 & 24.76 & 0.4 & 141 & 0.48 & 25.20 \\
\hline Takalar City to Barombong suburb & 181 & 21.88 & 0.4 & 173 & 0.52 & 23.21 \\
\hline
\end{tabular}


(a) the highest dominant business index is between Makassar City and Maros City with a value of 20,291; (b) the business index between Makassar City and the City Takalar is 14,465; (c) the business index between Makassar City and Sungguminasa City is 1,974. These results confirm that Makassar City's economic circulation toward the City of Maros is much better compared with other supporting cities. Thus, it can be stressed that the distance and mobility factors of the population are not directly related to the business index, but the business index is influenced more by the spatial function factor based on the strategic value of the location. Field data that support this finding indicate that the high business index is positively associated with the economic interaction between Makassar City and Maros City. This condition is influenced by the presence of Hasanuddin International Airport, the port, and the location of the industrial area. The smart city notion provides an integrated and systematic answer to challenges facing cities today and the difference between the effects of various public facilities on property values in the intra-urban environment (Zhu et al., 2019; Liu et al., 2016).

This result confirms that the strength of economic relations between the two places is not always directly proportional to the population and is inversely proportional to the distance between them. However, the function of strategic space is directly proportional to the economic interaction between two cities, in the sense that a greater economic index is not always related to the factor of the distance between two cities and the potential population. The spatial relationships between urban land-use intensity and urban vitality require immediate attention so as to put forward decision-making support and suggestions for future urban development and planning (Chekole et al., 2020).

Land use/land cover changes are the result of the interaction between humanity and nature, and they involve complex mechanisms and processes (Ali et al., 2020). Next, the centrality indicators of road proximity, internality, and straightness are extended by considering the node-based weights of the road class and road width (Cao et al., 2019).

The interaction between the core cities and the Mamminasata Metropolitan suburbs confirm that the spatial expansion of Makassar City tends to progress toward the outskirts of Manggala. This condition is more influenced by the attractiveness of the location, distance travelled, and developing economic activity. The actual economic and physical uses of land and properties influence land value (Hat \& Stoglehner, 2019).

Accessibility through the support of the transportation system contributes positively to the Metropolitan Mamminasata urban transport movement system. The highest accessibility is dominant toward the suburb of Barombong with a value of 1,33 . The condition is influenced by location factors, in the sense that the Barombong suburb is influenced by tourism activities located in the coastal areas. Furthermore, the highest stop point is more dominant toward the MoncongloePattalassang suburb, with a value of 21,35 . The analysis results confirm that the intensity of interaction in the core city of Makassar is directly proportional to the growth of the suburban Metropolitan Mamminasata urban area. In the process, it will impact economic agglomeration, gentrification, and limited land for 
preparing green open space. Generally, a spatially uneven distribution of green spaces is an effect of limited development regulations and the basis for the question of environmental justice (Zhang et al., 2018).

The periphery dynamics are the effects of the polarization of socioeconomic activities and the urban agglomeration of the core city as a unity of the Metropolitan Mamminasata urban system. The main drivers of urban polarization are the environment, policy systems, industrial structure, investment, scientific and technological innovation, location, and extroversion (Tan et al., 2016). Economic polarization, oriented toward the growth of urban areas, impacts population mobility, and circular migration toward Makassar City is relatively high. This condition is marked by traffic congestion in the main city road corridors and an increase in the urban population. Furthermore, economic agglomeration that continues to grow and expand leads to the growth of peripheral regions toward forming urban systems and the hierarchy of service centres. Thus, an integrated and comprehensive approach is needed to assess the sustainability and resilience of spatial structures in the context of local and regional development towards metropolitan urban spatial integration.

The urban agglomeration effect of Makassar's core city toward the Metropolitan suburb of Mamminasata affects the utilisation of water catchment areas, traffic congestion, and urban flooding. As such, several strategic and comprehensive steps toward sustainable development are needed. Thus, crosssectoral collaboration is needed, between regions and cities, and levels of government coupled with the involvement of the private sector and community participation in order to realize the sustainability of the Mamminasata Metropolitan urban development.entities, and economic, are spatially complex (Marcotullio \& Solecki, 2013).

The expansion of the Makassar core city space in the Metropolitan Mamminasata urban system (Figure 5), which runs parallel to spatial integration and interaction, led to the rapid and revolutionary growth of the periphery. We, therefore, argue that spatial interactions between city groups must be considered in future regional planning (Han \& Li, 2019). The polarization of socioeconomic activities in line with urban agglomeration impacts population mobility and circular migration. Furthermore, the effect of population mobility, of "chasing" in low urbanisation areas, is greater than the effects of agglomeration in high urbanisation areas, which promotes sustainable convergence of urbanisation between regions (Bausch \& Koziol, 2020).

Population mobility and circular migration due to economic polarization and urban agglomeration impact the formation of the hierarchy of Metropolitan Mamminasata urban service centres. Thus, urban systems, as both biophysical and economic entities, are spatially complex (Dushkoya \& Haase, 2020). Furthermore, as a major form of urbanisation, urban agglomeration integrates urban resources, adjusts industrial structures, narrows the gap between urban and rural areas, improves urban functions, strengthens urban competitiveness, and promotes regional sustainable development strategies (Quium, 2019; Azadi \& Vanhaute, 2019). 


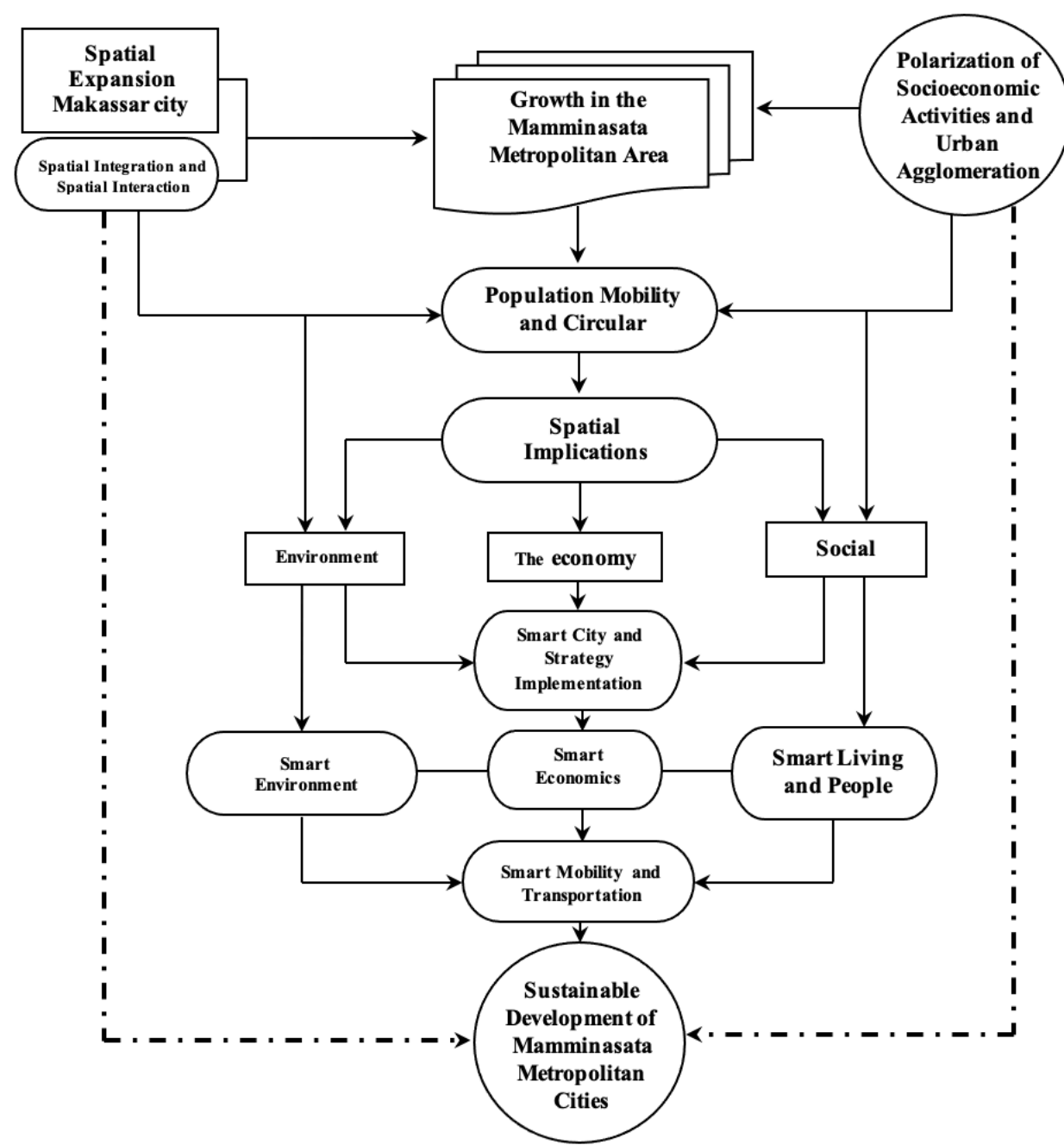

Figure 5. The concept of spatial integration and the growth of the Mamminasata Metropolitan area

There are three categories of impacts on the Mamminasata Metropolitan spatial system due to economic polarization and urban agglomeration. The first is the decline in environmental quality, which is a condition characterised by a reduction in land cover, utilisation of water catchment areas, urban flooding, waste disposal of urban activity, urban waste, and increased air pollution due to high traffic volume along the main road corridor. The decline in environmental quality will threaten the sustainability of the Metropolitan Mamminasata urban ecosystem. Effective and cross-cutting climate policy addressing mitigation and adaptation must be implemented not only at the global and national levels but also at the local level (Aerni, 2016).

Second, urban agglomeration, which tends to increase with economic agglomeration, causes a disparity in services between urban areas. This disparity is characterised by urban areas that are very fast developing, while other urban 
areas are very slow to develop. The concept of a nature-based solution has been developed in order to operationalize an ecosystem services approach within spatial planning policies and practices to integrate the ecological dimension fully and, at the same time, to address current societal challenges in cities (Przywojska et al., 2019). Furthermore, economic agglomeration that continues to increase impacts the income gap of the community, resulting in a dualistic economic activity pattern (formal and informal economy) along the main road corridor and has a positive association with the Metropolitan Mamminasata urban transportation system. Other interventions, such as investment and public policies, may be needed to encourage growth in central or secondary areas that are less attractive (Surya, 2015).

The third category is the emergence of new social problems in the dynamic development of the Mamminasata Metropolitan area. The social problems that develop are the effects of uncontrolled urban economic aggregation. This condition is characterised by inequality in land tenure, differences in people's lifestyles, poverty, urban crime, and other social problems in line with the acceleration of urban-suburban development. Even though efficacious land distribution allows societies to transition from poverty to a human capital-based developed economy, ongoing issues related to property rights, inequality, and the political economy of land distribution are unavoidable. Furthermore, the vital function of cities is to provide affordable infrastructure and institutional environments that enable migrants and other marginal urban communities to contribute to urban prosperity and problem-solving with their entrepreneurial skills, networks, and thinking (Surya et al., 2020).

Solving these three issues will require a coping strategy by involving the government, the private sector, and the community to work toward the sustainability of the Mamminasata Metropolitan urban development. Effectively tackling urban environmental, economic, and social problems will require implementing new approaches related to smart cities, the circular economy, and/or cultural diversity (Glasmeier \& Nebiolo, 2016). The proposed coping strategies related to this study are (i) environmental management based on optimizing the use of natural resources in the Metropolitan Mamminasata urban area to achieve a smart environment, (ii) sustainable economic growth to achieve a smart economy, (iii) handling social problems that are oriented toward equality, inclusivity, justice, and protection of the poor to realize smart living and smart people, and (iv) sustainable transportation management to realize smart mobility and smart transportation.

The strategy for achieving a smart urban environment requires three main actions, namely (i) information technology-based environmental management and (ii) information technology based on natural resource management and the development of renewable energy sources. Likewise, the strategy for realising smart economics requires three critical steps, namely, (i) the development of Metropolitan Mamminasata urban city branding, (ii) the development of local community-based entrepreneurship, and (iii) the development of e-commerce. Furthermore, smart living can be fulfiled through (i) ease of access to education 
services, (ii) ease of access to health services, (iii) development of the role of the media, (iv) ease of access to education security guarantees and development of technology-literate human resources, (v) research support, and (vi) development of the social and cultural character of the community.

Strategies for realizing smart mobility and smart transportation are (i) the development of information technology-based infrastructure networks, (ii) the development of urban transport based on information technology-based Metropolitan Mamminasata, and the development of information technologybased development and management systems. Strengthening the future development orientation of the Metropolitan Mamminasata urban area will require the support of smart governance through action, namely, (i) e-governance development and (ii) community participation in development planning. These results will direct the urban areas of the Mamminasata Metropolitan to (a) cities that are feasible, safe, and comfortable, (b) green cities that are climate- and disaster-resilient, and (c) smart cities that are competitive and technology-based. Public policy was established with primarily social objectives, including quality infrastructure, available and easily accessible schools, and efficient and equitable distribution of the benefits of public investments made in a fair manner (Allam \& Newman, 2018).

Adaptation to the Smart City concept is in line with the program of the Government of the Republic of Indonesia, in the sense that the smart city is the implementation of the concept of a metropolitan city that is able to manage natural resources effectively and efficiently, developing the capacity of human resources and other resources so that the Metropolitan Mamminasata urban community can live comfortably, safely, and sustainably. The technology inherent in Smart Cities promises efficiency and options to enable cities to become more inclusive, safe, resilient and sustainable, as required by the UN agenda, including cultural heritage (Li et al., 2019). Furthermore, it is very significant for the integrated development of smart cities and the intensification of the hardware environment, so it is a real achievement in the transition from information islands to information sharing and interconnection for urban informationization (Li et al., 2019).

\section{Conclusions}

Spatial expansion, spatial integration, spatial interactions, urban agglomeration, spatial use, and transportation systems have a significant effect on the mobility of residents of suburban areas. The acceleration of Metropolitan Mamminasata Metropolitan urban development toward core-periphery relations is strongly influenced by the space, location, distance, and position of the Makassar core city. The role and function of the core city space become the driving forces of population mobility and circular migration toward core-periphery relations. A very intensive core-periphery relationship in line with population mobilisation and circular migration leads to reduced land cover and increased urban flooding 
and environmental degradation. Arrangement of spatial use is needed by dividing the spatial zones and distribution of Metropolitan Mamminasata urban services based on their hierarchy in establishing service centres and connectivity of the Metropolitan Mamminasata urban transportation system. Determination of the function of Metropolitan Mamminasata urban activities in its formulation requires consideration of the proximity factor and ease of transport from the settlement location to the location of socioeconomic activities to reduce traffic volume and congestion in the main Mamminasata Metropolitan urban main road corridor.

The spatial interaction and urban agglomeration, as a determinant of the connectivity of the transportation system and the growth of the periphery area, require the support of the implementation of the concept of sustainable smart cities as an integrated Metropolitan Mamminasata urban system. Furthermore, variations in typology and morphology of the periphery cause differences in spatial interactions and population mobility in the urban spatial scale of Metropolitan Mamminasata. The strength of spatial interaction and population mobility is influenced by three main factors, namely, (i) the accumulation and polarization of the commercial space functions of the Makassar core city, (ii) the strategic value of the location in relation to the function of the developing economic space, and (iii) accessibility to the Metropolitan urban transportation system Mamminasata. On that basis, it is essential to establish the urban spatial zone, the development of mass transportation systems from the periphery to the core city, and the integration of the transportation system with economic growth, smart mobility, and urban smart transportation of Metropolitan Mamminasata.

The rapid growth of the suburban metropolis of Metropolitan Mamminasata will require zoning arrangements for effective and efficient use of space. Connectivity and integration of core-suburban systems in the urban context of the Metropolitan Mamminasata will require the distribution of services in urban socioeconomic activities and the formation of a hierarchy of service centres. Metropolitan Mamminasata Metropolitan urban development in the future is oriented toward implementing the smart city concept as an effort toward sustainable development. The strategies and follow-up needed are (i) strengthening the government and resource capacity of the Mamminasata Metropolitan urban community, (ii) controlling excessive urban agglomeration in order to reduce the burden of environmental pollution and maximum compaction in specific locations, (iii) developing the Metropolitan Mamminasata urban area's disaster resilience and environmentally friendly systems, and (iv) creating social cohesion for the sustainability of the lives of citizens who are safe, comfortable, and globally competitive. This idea requires support for strengthening the capacity of the smart governance-based government in terms of decision making and optimization of public services. 


\section{Acknowledgements}

The authors are thankful for the participation of stakeholders in contributing ideas to this study and to the Ministry of Research and Technology of the Republic of Indonesia for their support and financial assistance in carrying out this research.

\section{References}

Abshirini, E. and Koch, D. (2016). "Rivers as integration devices in cities", City Territory and Architecture, vol. 3, no. 1, p. 1-21.

Aerni, P. (2016), "Coping with Migration-Induced Urban Growth: Addressing the Blind Spot of UN Habitat", Sustainability, vol, 8, no. 8, p. 800.

Allam, Z. and Newman, P. (2018), "Redefining the Smart City: Culture, Metabolism and Governance", Smart Cities, vol. 1, no. 1, p. 4-25.

Alverti, M.N., Themistocleous, K., Kyriakidis, P.C. and Hadjimitsis, D.G. (2020), "A Study of the Interaction of Human Smart Characteristics with Demographic Dynamics and Built Environment: The Case of Limassol, Cyprus", Smart Cities, vol. 3, no. 1, p. 48-73.

Ali, L., Haase, A. and Heiland, S. (2020), "Gentrification through Green Regeneration? Analyzing the Interaction between Inner-City Green Space Development and Neighborhood Change in the Context of Regrowth: The Case of Lene-Voigt-Park in Leipzig, Eastern Germany", Land, vol. 9, no. 1, p. 24.

Al Jarah, S.H., Zhou, B., Abdullah, RJ., Lu, Y. and Yu, W. (2019), "Urbanization and Urban Sprawl Issues in City Structure: A Case of the Sulaymaniah Iraqi Kurdistan Region", Sustainability, vol. 11, no. 2, p. 485.

Arsanjani, J.J., Helbich, M. and Vaz, E.D.N. (2013), "Spatiotemporal simulation of urban growth patterns using agent-based modeling: The case of Tehran", Cities, vol. 32, p. 33-42.

Azadi, H. and Vanhaute, E. (2019), "Mutual Effects of Land Distribution and Economic Development: Evidence from Asia, Africa, and Latin America", Land, vol. 8 , no. 6 , p. 96 .

Bausch, T. and Koziol, K. (2020), "New Policy Approaches for Increasing Response to Climate Change in Small Rural Municipalities", Sustainability, vol. 12, no. 5, p. 1894 .

Brandl, J. and Zielinska, I. (2020), "Reviewing the Smart City Vienna Framework Strategy's Potential as an Eco-Social Policy in the Context of Quality of Work and Socio-Ecological Transformation", Sustainability, vol. 12, no. 3, p. 859.

BPS Provinsi Sulawesi Selatan (2019), Sulawesi Selatan Dalam Angka, Penerbit Badan Pusat Statistik Sulawesi Selatan, Makassar.

Creswell, J.W. (2016), Research Design. Qualitative, Quantitative and Mixed Methods Approach. $4^{\text {th }}$ Edition, Pustaka Pelajar, Jakarta.

Cochran, W.G. (1991), Teknik Penarikan Sampel. Edisi Ketiga, Penerbit Universitas Indonesia, Depok. 
Couclelis, H. (2000), "From Sustainable Transportation to Sustainable Accessibility: Can We Avoid a New Tragedy of the Commons?" in D.J. Janelle and D.C. Hodge, Information, Place, and Cyberspace: Issues in Accessibility, Springer, Berlin, p. 341-356.

Chen, Y., John Zacharias, J. and Zeng, M. (2020), "Searching for the Center: A New Civic Role for the Central Business District in China", Sustainability, vol. 12, no. 3, p. 866 .

Chen, H., Sun, D., Zhu, Z. and Zeng, J. (2016), "The Impact of High-Speed Rail on Residents' Travel Behavior and Household Mobility: A Case Study of the Beijing-Shanghai Line, China", Sustainability, vol. 8, no. 11, p. 1187.

Cao, X., Liang, F., Chen, H. and Liu, Y. (2017), "Circuity Characteristics of Urban Travel Based on GPS Data: A Case Study of Guangzhou", Sustainability, vol. 9, no. 11, p. 2156.

Chen, Y., Zhang, Z. and Liang, T. (2019), "Assessing Urban Travel Patterns: An Analysis of Traffic Analysis Zone-Based Mobility Patterns", Sustainability, vol. 11, no. 19 , p. 5452.

Chekole, S.D., de Vries, W.T. and Shibeshi, G.B. (2019), "An Evaluation Framework for Urban Cadastral System Policy in Ethiopia", Land, vol. 9, no. 2, p. 60.

Cao, X., Zhou, B., Shi, Y. and Pei, X. (2019), "The Unbalanced Analysis of Economic Urbanization-A Case Study of Typical Cities in China", ISPRS International Journal. Geo-Information, vol. 9, no. 1, p. 13.

Dushkova, D. and Haase, D. (2020), "Not Simply Green: Nature-Based Solutions as a Concept and Practical Approach for Sustainability Studies and Planning Agendas in Cities", Land, vol. 9, no. 1, p. 19.

Fan, Y., Zhang, S., He, Z., He, B., Yu, H., Ye, X., Yang, H., Zhang, X. and Chi, Z. (2018), "Spatial Pattern and Evolution of Urban System Based on Gravity Model and Whole Network Analysis in the Huaihe River Basin of China", Discrete Dynamics in Nature and Society, vol. 2018, p. 1-11.

Geurs, K. and Wee, B. (2004), "Accessibility evaluation of land-use and transport strategies: review and research directions", Journal of Transport Geography, vol. 12, no. 2, p. 127-140.

Giyarsih, S.R. (2001), "Gejala Urban Sprawl Sebagai Pemicu Proses Densifikasi Permukiman di Daerah Pinggiran Kota (Urban Fringe Area)", Jurnal Perencanaan Wilayah dan Kota, vol. 12, no. 1, p. 40-45.

Girard, L.F. and Nocca, F. (2019), "Moving Towards the Circular Economy/City Model: Which Tools for Operationalizing This Model?", Sustainability, vol. 11, no. 22, p. 6253 .

Glasmeier, A.K. and Nebiolo, M. (2016), "Thinking about Smart Cities: The Travels of a Policy Idea that Promises a Great Deal, but So Far Has Delivered Modest Results", Sustainability, vol. 8, no.11, p. 1122.

Grădinaru, S.R., Iojă, C.I. and Stupariu, I.P. (2015), "Do Post-Socialist Urban Areas Maintain their Sustainable Compact Form? Romanian Urban Areas as Case Study", Journal of Urban and Regional Analysis, vol. 7, no. 2, p. 129-144. 
Ha, N.M., Dang Le, N. and Trung-Kien, P. (2019), "The Impact of Urbanization on Income Inequality: A Study in Vietnam", Journal Risk Financial Management, vol. 12, no. 3, p. 146.

Hat, K. and Stöglehner, G. (2019)," How Resilient is Growth? Resilience Assessment of Austrian Municipalities on the Basis of Census Data from 1971 to 2011 ", Sustainability, vol. 11, no. 6, p. 1818.

Healey, P. (2007), Urban Complexity and Spatial Strategies Toward Spatial Strategis: Towads A Relational Planning for our Times, Taylor \& Francis Ltd.

Hesse, M. and Siedentop, S. (2018), "Suburbanisation and Suburbanisms-Making Sense of Continental European Developments", Raumforschung und Raumordnung/Spatial Research and Planning, vol. 76, p. 97-108.

Hong, R., Rao, W., Zhou, D., An, C., Lu, Z. and Xia, J. (2020), "Commuting Pattern Recognition Using a Systematic Cluster Framework", Sustainability, vol. 12, no. 5, p. 1764 .

Horak, J., Tesla, J., Fojtik, D. and Vozenilek, V. (2019), "Modelling Public Transport Accessibility with Monte Carlo Stochastic Simulations: A Case Study of Ostrava", Sustainability, vol. 11, no. 24, p. 7098.

Hyoung, T. and Gim, T. (2018), "An Analysis of the Relationship between Land Use and Weekend Travel: Focusing on the Internal Capture of Trips", Sustainability, vol. 10, no. 2, p. 425.

Hoang, A.T., Apparicio, P. and Hien Pham, T.T. (2019), "The Provision and Accessibility to Parks in Ho Chi Minh City: Disparities along the Urban CorePeriphery Axis", Urban Science, vol. 3, no. 1, p. 37.

Han, J. and Liu, J. (2018), "Urban Spatial Interaction Analysis Using Inter-City Transport Big Data: A Case Study of the Yangtze River Delta Urban Agglomeration of China", Sustainability, vol. 10, no. 12, p. 4459.

Han, H. and Li, H. (2019), "Coupling Coordination Evaluation between Population and Land Urbanization in Ha-Chang Urban Agglomeration", Sustainability, vol. 12, no. 1, p. 357.

Janssens, X., Bruneau, E. and Lebrun, P. (2006), "Prediction of the potential honey production at the apiary scale using a Geographical Information System (GIS)", Apidologie, vol. 37, no. 3, p. 351-365.

Jiang, Y., Hou, L., Shi, T. and Ning, Y. (2018), "Spatial Zoning Strategy of Urbanization Based on Urban Climate Co-Movement: A Case Study in Shanghai Mainland Area", Sustainability, vol. 10, p. 2706.

Jing, P., Zhao, M., He, M. and Chen, L. (2018), "Travel Mode and Travel Route Choice Behavior Based on Random Regret Minimization: A Systematic Review", Sustainability, vol. 10, no. 4, p.1185.

Kuchiki, A. (2020), "On 'Economies of Sequence' in the Architectural Theory of Agglomeration: A Case of the Kyoto Tourism Industry", Economies, vol. 8, no. 1, p. 15.

Kurek, S., wójtowicz, M. and Gałka, J. (2015), "The changing role of migration and natural increase in suburban population growth: The case of a non-capital post-socialist city (the Krakow Metropolitan Area, Poland)", Moravian Geographical Reports, vol. 23, no. 4, p. 59-70. 
Lan, F., Da, H., Wen, H. and Wang, Y. (2019), "Spatial Structure Evolution of Urban Agglomerations, and Its Driving Factors in Mainland China: From the Monocentric to the Polycentric Dimension", Sustainability, vol. 11, no. 3, p. 610.

Loibl, W., Etminan, G., Gebetsroither-Geringer, E., Neumann, H-M. and Sanchez-Guzman, S. (2018), "Characteristics of Urban Agglomerations in Different Continents: History, Patterns, Dynamics, Drivers and Trends" in M. Ergen (ed) Urban Agglomeration, p. 29-63.

Lee, C. and Kim, E. (2017), "Mobility of Workers and Population between Old and New Capital Cities Using the Interregional Economic Mode", Sustainability, vol. 9, no. 10, p. 1872.

Liu, C., Bin Yu, B., Zhu, Y., Liu, L. and Li, P. (2019), "Measurement of Rural Residents' Mobility in Western China: A Case Study of Qingyang, Gansu Province", Sustainability, vol. 11, no. 9, p. 2492.

Luiu, C., Tight, M. and Burrow, M. (2018), "Factors Preventing the Use of Alternative Transport Modes to the Car in Later Life", Sustainability, vol. 10, no. 6, p. 1982.

Liu, Y., Chen, J., Wu, W. and Ye, J. (2019), "Typical Combined Travel Mode Choice Utility Model in Multimodal Transportation Network", Sustainability, vol. 11 , no. 2, p. 549.

Liu, X., Zhang, S., Zeng, J. and Fan, F. (2019), "Analysis and Optimization Strategy of Travel System for Urban Visually Impaired People", Sustainability, vol. 11, no. 6, p. 1735 .

Lim, J. and Kim, J.H. (2018), "Joint Determination of Residential Relocation and Commuting: A Forecasting Experiment for Sustainable Land Use and Transportation Planning", Sustainability, vol. 11, no. 1, p. 182.

Li, C., Liu, X., Dai, Z. and Zhao, Z. (2019), "Smart City: A Shareable Framework and Its Applications in China", Sustainability, vol. 11, no. 16, p. 4346.

Maheshwari, B., Singh, V.P. and Thoradeniya, B. (2016), Balanced Urban Development: Is It a Myth or Reality?, Springer Open.

Marcotullio, P.J. and Solecki, W. (2013), "What is a city? An essential definition for sustainability" in C.G. Boone and M. Fragkias (eds), Urbanization and Sustainability: Linking Urban Ecology, Environmental Justice, and Environmental Change, Springer, New York, NY, USA.

McGee, T. G., and Robinson, Ira M. (eds) (1995), The Mega-Urban Regions of Southeast Asia, UBC Press, Vancouver.

Mouzughi, Y., David Bryde, D. and Al-Shaer, M. (2014), "The Role of Real Estate in Sustainable Development in Developing Countries: The Case of the Kingdom of Bahrain", Sustainability, vol. 6, p. 1709-1728.

Nugmanova, A., Arndt, W.H., Hossain, Md.A. and Kim, Jr. (2019), "Effectiveness of Ring Roads in Reducing Traffic Congestion in Cities for Long Run: Big Almaty Ring Road Case Study", Sustainability, vol. 11, p. 4973.

Neiderud, C-J. (2015), "How urbanization affects the epidemiology of emerging infectious diseases", Infection Ecology E Epidemiology, vol. 5, p.1-9.

Park, T., Kim, M., Jang, C., Choung, T., Sim, K.A., Seo, D. and Chang, S.I. (2018), "The Public Health Impact of Road-Traffic Noise in a Highly - Populated City, 
Republic of Korea: Annoyance and Sleep Disturbance", Sustainability, vol. 10, no. 8, p. 2947.

Pinto, S.M. (2002), "Residential Choice, Mobility, and the Labor Market", Journal Urban Econonomic, vol. 51, no. 3, p. 469-496.

Przywojska, J., Krzykacz, A.P. and Wiktorowicz, J. (2019), "Perceptions of Priority Policy Areas and Interventions for Urban Sustainability in Polish Municipalities: Can Polish Cities Become Smart, Inclusive and Green?", Sustainability, vol. 11, no. 14, p. 3962.

Quium, A.S.M. (2019), "Transport Corridors for Wider Socio-Economic Development", Sustainability, vol. 11, no. 19, p. 5248.

Ravetz, J., Fertner, C. and Sick Nielsen, T.A. (2013), Peri-urban futures: Scenarios and models for land use change in Europ, Springer.

Roberts, M., Gil Sander, F. and Tiwari, S. (2019), Realizing Indonesia's Urban Potential 2045. Work Bank Group.

Schreiber, S. J. and Kelton, M. (2015), "Sink habitats can alter ecological outcomes for competing species", Journal of Animal Ecology, vol. 74, no. 6, p. 995-1004.

Scheuer, S., Haase D. and Volk, M. (2016), "On the Nexus of the Spatial Dynamics of Global Urbanization and the Age of the City", PLoS ONE, vol. 11, no. 8, p. e0160471.

Sheng Chang, H. and Lin Chiu, S. (2013), "Discussion on sustainable land use allocation toward the sustainable city A practice on Linco New Town", Procedia Environmental Sciences, vol. 17, p. 408-417.

Sassen, S. (1991), The global city: New York, London, Tokyo, Princeton University Press, Princeton.

Starkey, P. and Hine, J. (2014), Poverty and sustainable transport How transport affects poor people with policy implications for poverty reduction A literature review, UN Habitat, Overseas Development Institute (ODI) and SLoCaT.

Sugiono. (2016), Metode Penelitian dan Pengembangan untuk Bidang Pendidikan Manajemen Sosial Teknik, Penerbit. Alfabeta. Bandung.

Surya, B., Syafri, S., Sahban, H. and Sakti, H.H. (2020), "Natural Resource Conservation Based on Community Economic Empowerment: Perspectives on Watershed Management and Slum Settlements in Makassar City, South Sulawesi, Indonesia", Land, vol. 9, no. 4, p. 104.

Surya, B., Ahmad, D.N.A., Sakti, H.H. and Sahban, H. (2020), "Land Use Change, Spatial Interaction, and Sustainable Development in the Metropolitan Urban Areas, South Sulawesi Province, Indonesia", Land, vol. 9, no. 3, p. 95.

Surya, B. (2015), "Optimization of Function and Role of Traditional Markets in Urban Development System of Ketapang City: a case study: Range Sentap Market, Delta Pawan Subdistrict, Ketapang city", World Applied Sciences Journal, vol. 33, no. 9, p. 1457-1471.

Surya, B. (2016), "Change Phenomena of Spatial Physical in the Dynamics of Development in Urban Fringe Area", Indonesian Journal of Geography, vol. 48, no. 2. p. 118-134. 
Tan, R., Zhou, K., He, Q. and Xu, H. (2016), "Analyzing the Effects of Spatial Interaction among City Clusters on Urban Growth-Case of Wuhan Urban Agglomeration", Sustainability, vol. 8, p. 759.

Twumasi, P.A., Alele, F., Smith, A.M., Emeto, T.I., Lindsay, D., Tsey, K. and Aduli, B.M. (2020), "Prioritising Family Needs: A Grounded Theory of Acculturation for Sub-Saharan African Migrant Families in Australia", Social Science, vol. 9, no. 2, p. 17.

Utami, S.D. (2015), "Foreign Direct Investment and Regional Develompment in Jakarta Metropolitan Area. Sustainable Megacities: vulnerability, diversity, and livability", The $5^{\text {th }}$ International Conference of Jabodetabek Studi Forum, p. 495-505.

Vidović, K., Šoštarić, M., Mandžuka, S. and Kos, G. (2020), "Model for Estimating Urban Mobility Based on the Records of User Activities in Public Mobile Networks", Sustainability, vol. 12, no. 3, p. 838.

Vijayakumar, S. (2013), "An Empirical Study on the Nexus of Poverty, GDP Growth, Dependency Ratio and Employment in Developing Countries", Journal of Competitiveness, vol. 5, no. 2, p. 67-82.

Wan, Y., Deng, C., Wu, T., Jin, R., Chen, P. and Kou, K. (2019), "Quantifying the Spatial Integration Patterns of Urban Agglomerations along an Inter-City Gradient", Sustainability, vol. 11, no. 18, p. 5000.

Wagistina, S. and Wahab, F.R. (2019), "Income Distribution Between Local and Migrant Households in Pheri-Urban of Malang City, East Java Province, Indonesia", Wacana, vol. 22, no. 4, p. 290-296.

Wrede, M. (2001), "Commuting Expenses Be Tax Deductible? A Welfare Analysis", Journal Urban Economic, vol. 49, no. 1, p. 80-99.

Wen, L., Kenworthy, J., Guo, X. and Marinova, D. (2019), "Solving Traffic Congestion through Street Renaissance: A Perspective from Dense Asian Cities", Urban Science, vol. 3, no. 1, p. 18.

Wu, W., Liang, Y. and Wu, D. (2016), "Evaluating the Impact of China's Rail Network Expansions on Local Accessibility: A Market Potential Approach", Sustainability, vol. 8, no. 6, p. 512.

Wei, C., Taubenbock, H. and Blaschke, T. (2017), "Measuring urban agglomeration using a city-scale dasymetric population map: A study in the pearl river delta, China", Habitat International, vol. 59, p.32-43.

Woltjer, J. (2014), "A Global Review on Peri-Urban Development and Planning", Jurnal Perencanaan Wilayah dan Kota, vol. 25, no.1, p.1-16.

White, M.J., Muhidin,S., Andrzejewski, C., Tagoe, E., Knight, R. and Reed, H. (2008), "Urbanization and fertility: An event-history analysis of Coastal Ghana", Demography, vol. 45, p. 803-816.

Wenner, F., Dang, KA., Hölzl, M., Pedrazzoli, A., Schmidkunz, M., Wang, J. and Thierstein, A. (2020), "Regional Urbanisation through Accessibility? - The "Zweite Stammstrecke" Express Rail Project in Munich", Urban Science, vol. 4, no.1, p. 2. 
Xia, C., On Yeh, A.G. and Zhang, A. (2020), "Analyzing spatial relationships between urban land use intensity and urban vitality at street block level: A case study of five Chinese megacities", Landscape and Urban Planning, vol.193, p.1-18. Yanbo, Q., Guanghui, J., Yuting, Y., Qiuyue, Z., Li Yuling, L. and Wenqiu, M. (2018), "Multi-scale analysis on spatial morphology differentiation and formation mechanism of rural residential land: A case study in Shandong Province, China", Habitat International, vol. 71, p. 135-146.

Yuan, F., Wei, YD. and Wu, J. (2020), "Amenity effects of urban facilities on housing prices in China: Accessibility, scarcity, and urban spaces", Cities, vol. 96, p. 1-11.

Zhang, X., Guan, H., Zhu, H. and Zhu, J. (2019), "Analysis of Travel Mode Choice Behavior Considering the Indifference Threshold", Sustainability, vol. 11, no. 19, p. 5495.

Zhu, B., Zhu, X., Zhang, R. and Zhao, X. (2019), "Study of Multiple Land Use Planning Based on the Coordinated Development of Wetland Farmland: A Case Study of Fuyuan City, China", Sustainability, vol. 11, no. 1, p. 271.

Zhang, X., Chen, Y. and Li, M. (2018), "Research on Geospatial Association of the Urban Agglomeration around the South China Sea Based on Marine Traffic Flow", Sustainability, vol. 10, no. 9, p. 3346. 